\title{
More Flexible Working, More Productive Workers?
}

\author{
(Case in Pandemic Situation)
}

\author{
Metha Djuwita Supriatna*, Nisha Faradilla Sofiani, Nadiarani Anindita \\ Politeknik STIA LAN Bandung \\ Bandung, Indonesia \\ *methadjuwita@gmail.com
}

\begin{abstract}
While globally the Covid-19 pandemic is at different stages and far from under control in some countries, it reveals that the organisation in any sector faces a simple and complex problem about health issues and organisational problems such as managing people remote working areas. Adaptive personnel policies are introduced, such as work from home, online or digital meeting, and flexible work arrangement to effectively manage the individual issue. In this article, we empirically test models of perceived productivity among employees in a pandemic situational context. The research questions guiding this work are: How well flexible working arrangements could foster productivity among employees in the pandemic outbreak. Using convenience sampling, about 52 employees from various organisations participate as respondents in this research. Data were collected through questionnaires in which participants completed measures of flexible working arrangements and perceived productivity. The quantitative methodology was used, and regression analysis applied to analyse the effect of flexible work arrangements on perceived productivity. Our results show that the progression of productivity through flexible working is linear. More flexible work arrangements for employees would play a significant role in the greater perceived productivity. Findings also indicate that flexible work arrangements accounted for 0.329 of the variances in perceived productivity. The study findings suggest the importance of flexible working arrangements getting employees on the right track in building better productivity. The implications of these findings and directions for future research are addressed and discussed in this study.
\end{abstract}

Keywords—flexible working arrangements, perceived productivity, pandemic outbreak

\section{INTRODUCTION}

Covid 19 was confirmed by the Government to enter Indonesia in early March 2020, the spread of Covid 19 has increased. To maintain business continuity, since April 2020, various policies related to human resources have been issued by the government to suppress the growth of Covid 19, particularly in changing the work system. If before the pandemic, the work system that was usually applied was the work system from the office (WFO), then during the pandemic there were several other work system terms, such as the work from the home system (WFH), the combination work system between WFH and WFO, and the flexible working arrangements (FWA).

Flexible working arrangement and work from home systems is not a new thing, this concept is part of the concept of telecommuting and has even been studied extensively since in the late 1970s, as an effort to solve traffic jams from home to office trips and office to home, at that time. In Indonesia itself, the flexible work system application has only been carried out on a large scale forcibly to prevent positive Covid 19 and is carried out at government offices and private companies. The organisation's flexible work system is basically a remote work system, where during this pandemic, workers are asked to work from home, which is done with the support of technology. Coordination of work implementation can be done through email applications, instant messages, zoom meetings, etc.

Under normal conditions, implementing a flexible working system will be important not only for women workers but also for men. If initially, employees will seek flexibility to manage the balance between work and family life, a flexible work system can also allow workers to meet other needs related to commitments, such as sports, involvement in the community, and even recreational activities can be accommodated [1].

The productivity of remote workers is of critical concern to organisations and managers contemplating a flexible working arrangement. A research result shows that the application of flexible work systems plays an important role in the perception of worker productivity [2].

Perceived productivity can be defined as workers' perceptions of their work results. Of course, working during this pandemic has its own challenges, especially when workers work from home. Therefore, this study aims to see how respondents' beliefs about flexible working arrangement effectiveness affect workers' perceived productivity.

\section{LITERATURE REVIEW}

\section{A. Flexible Working Arrangements}

Flexible working arrangements defined as the completion of work-related tasks from a different location from the office and has technology support [3]. Technology support in 
question is the role of computer information technology applications that can connect workers to their workplaces, such as the internet, telephone, email, instant messaging, and web conferencing. Also, a flexible working arrangement is defined as an effort to complete the work carried out by employees, either in part or all of their jobs work in a physical location that is separate from the employer, for example, homes, hotels, and others [4].

There is a positive result related to the psychological contract between the employee and the employer, where when the employer offers the option to work flexibly, the employee feels the need to respond by providing higher commitment, loyalty, and job performance. Furthermore, these cases are more likely to occur in women and employees who have children [5]. Most of the research results also show a positive impact by implementing flexible working arrangements, reducing absenteeism, and increasing productivity [6], reducing physical, psychological, and work stress [7]. Besides, especially for female workers who work with the flexible working arrangement and more family-friendly, can result in lower absenteeism, and higher job satisfaction [8].

There are many benefits to working remotely but not without obstacles and problems. Some of the problems include (i) workers accustomed to a conventional office atmosphere who have difficulty coordinating with colleagues. It needs tidier work scheduling it may even need to set a fixed time for gathering at the office; (ii) there is no clear boundary between office and home, and there is even a tendency for working hours to be unlimited; (iii) remote workers tend to appear unemployed and have an impact on relationships with neighbours and family. Families and neighbours may become angry when remote workers do not participate in household and environmental work, even though they are at home. Meanwhile, for company/organisation leaders, some of the obstacles that may arise include (i) some leaders have difficulty adjusting, especially for leaders who tend to lack confidence in their subordinates; (ii) in jobs that require a high intensity of group cooperation, it is necessary to arrange a schedule of meetings which will be troublesome; (iii) types of work requiring direct contact with customers only allow limited free work, not all the time away from the office. Meanwhile, when only some workers can work remotely, this will create a sense of injustice among workers. (iv) some workers cannot work without supervision [9].

\section{B. Perceived Productivity}

Gren [10] explained that perceived productivity is basically the perception of workers on their work results. In its simplest definition, work productivity is the output per unit of input, for example, production output per labour hours. Productivity is traditionally defined as the ratio of outputs to inputs. More specifically, it refers to the relationship between what comes out of a system and what is consumed [11]. At a workplace level, work productivity is influenced by many factors, including the input of the individual worker - worker productivity [12]. For a society or an industry, worker productivity is one of many factors contributing to indicators of the workplace's success and that business's well-being.

The results of the Neufeld and Fang [13] study, which attempted to link perceived productivity with the application of remote work systems, shows that telecommuter beliefs and attitudes, and the quality of their social interactions with managers and family members, were strongly associated with productivity. Furthermore, telecommuters' social interactions with colleagues, managers, and family members strongly influenced their telecommuting beliefs and attitudes. Research shows that increased productivity may occur due to reduced work interruptions and the use of optimally efficient hours $[14,15]$. However, productivity reductions may occur due to inaccessible IT resources and reduced interaction opportunities [2]. Also, the results of empirical studies have found that young families experience an increase in role conflict, which can lead to decreased productivity [16].

\section{METHODS}

This research uses quantitative methods with verification methods. The verification method is used to analyse the impact of flexible working arrangements on perceived worker productivity. Using convenience sampling, 52 participants participated in this study and stated that they have or are currently implementing a flexible work system. The participants were individuals employed in a variety of settings. The sample included employees from private organisations and public organisations.

Data were collected using a questionnaire that was distributed online. The questionnaire distributed contains the two research variables used: flexible working arrangement and perceived productivity variables.

Flexible working arrangement adapted from Albion [17] and Gamal Aboelmaged and Mohamed el Subbaugh [3], consisting of 18 indicators. The questionnaire is used to measure respondents' attitudes towards flexible work systems. Meanwhile, the variable perceived productivity was adapted from Staples et al. [2]. All indicators use a Likert scale of 1 to 5 from strongly disagree to agree with each indicator statement strongly.

\section{RESULTS AND DISCUSSION}

Validity and reliability testing are carried out before the data is analysed further. Regarding indicators that are declared unreliable, these indicators are not used further. For the variable perceived productivity, all indicators are declared valid and reliable. While the flexible working arrangement variable, out of 18 indicators, only 7 indicators were declared valid and reliable, so these 7 indicators were then used in further testing.

The following table shows the average score results for the flexible working arrangement variables and the variable perceived productivity. For a flexible working arrangement, all 
indicators are in the high category. Workers claim that flexible work arrangements help workers balance life commitments, working more flexible working hours is very important for workers to carry out other responsibilities and activities outside of work, flexible work arrangements are essential for workers to manage workload variations and worker responsibilities, flexible work arrangements make workers focus more on their work when they are in the workplace, workers can work outside the office on weekdays. Workers also claim that the work environment is flexible.

All indicators of perceived productivity are in the high category. Workers claim that workers believe they are effective workers, workers believe that their performance is above average compared to colleagues, workers believe in their work quality, workers judge that they are working efficiently, and workers believe that they have high productivity. The supervisor of the worker believes that the worker is an efficient worker.

TABLE I. THE AVERAGE SCORE OF THE INDICATOR

\begin{tabular}{|c|c|c|c|c|c|}
\hline \multicolumn{7}{|c|}{ Flexible Working Arrangement } & \multicolumn{3}{|c|}{ Perceived Productivity } \\
\hline Item & Mean & Category & Item & Mean & Category \\
\hline 1 & 3.73 & High & 1 & 3.87 & High \\
\hline 2 & 3.67 & High & 2 & 3.65 & High \\
\hline 3 & 3.67 & High & 3 & 3.75 & High \\
\hline 4 & 3.83 & High & 4 & 3.85 & High \\
\hline 5 & 3.79 & High & 5 & 3.83 & High \\
\hline 6 & 3.59 & High & 6 & 3.58 & High \\
\hline 7 & 3.52 & High & & & \\
\hline
\end{tabular}

The average total score for the flexible working arrangement variable is 3.68 , and the variable perceived productivity is 3.75 , and these two variables are in the high category (Table 1). This means that the initiative to implement a flexible work system was welcomed positively by workers. This can occur because workers think that a flexible working arrangement can balance home and work life and feel that a flexible workplace can increase workers' enthusiasm for work. The average score for a flexible working arrangement which is in the high category can still be improved by supporting workers by providing technology that makes it easier for workers to coordinate in completing tasks, setting up virtual regular meetings, adjusting working hours so that work can be done more effectively, and given trust by the organisation or manager so that workers can be more comfortable when doing work.

Then, perceived productivity in the high category shows that workers feel that they can work effectively during flexible working arrangements. However, perceived productivity can still be increased to a high level, with good interaction between workers and managers, co-workers, and family members; optimally use efficient working hours, facilitate workers' access to information technology, and seek any interference errors are encountered during flexible work arrangements.
TABLE II. Average Total VARIABLE. SCORE

\begin{tabular}{|l|l|l|}
\hline Variable & Mean & Category \\
\hline FWA & 3.68 & High \\
\hline Perceived Productivity & 3.75 & High \\
\hline
\end{tabular}

Simple regression testing is used in this study to examine the effect of flexible working arrangements on perceived productivity. The results show that a constant value of (a) 10.511 indicates a constant positive value (table 2). So, when the flexible working arrangement is zero, the growth in perceived productivity will be 10,511 . It was then found that the regression coefficient of flexible working arrangements was 0.466 , which indicated a direct relationship between flexible working arrangements and perceived productivity. Thus, the application of flexible working arrangements will also increase worker perceived productivity (table 3 ).

TABLE III. REgRESSION TEST RESULTS

\begin{tabular}{|l|l|l|l|l|l|}
\hline \multirow{2}{*}{} & \multicolumn{3}{|c|}{ Unstandardised Coefficients } & \multirow{2}{*}{ T } & Sig. \\
\cline { 2 - 4 } & \multicolumn{1}{|c}{ B } & Std. Error & Beta & & \\
\hline (Constant) & 10.511 & 2.471 & & 4.254 & .000 \\
\hline FWA & .466 & .094 & .574 & 4.954 & .000 \\
\hline
\end{tabular}

To see the direction and strength of the relationship between the two variables, it can be seen in the table 4 below. The value of $\mathrm{R}=0.574$ shows the coefficient of the relationship between the two variables. This means that there is a moderate relationship between the variable, flexible working arrangement, and perceived productivity. Then, the R Square value obtained from the test results is 0.329 . This means that workers' perceived productivity can be explained by applying a flexible working arrangement, and the rest can be explained by other factors outside the variables studied.

TABLE IV. DETERMinAtion CoEFFicient VALUe

\begin{tabular}{|l|l|l|}
\hline Model & R & R Square \\
\hline 1 & .574 & .329 \\
\hline
\end{tabular}

The t-test is then carried out to test the hypothesis of applying a flexible working arrangement on perceived productivity. The hypothesis tested in this study is $\mathrm{H}_{0}=$ Variable; a flexible working arrangement does not affect the worker's perceived productivity. The degrees of freedom df can be found by performing the following calculations: $\mathrm{df}=\mathrm{n}-2=$ $52-2=50$, while the significance level used in this study is $5 \%$. By using the t table, the researcher can find that the t-table value is 1.67591 . Meanwhile, the t-count value obtained from the regression test results obtained an at-count value of 4.954. With the test criteria, $\mathrm{H}_{0}$ is rejected, if $\mathrm{t}$-count $\geq \mathrm{t}$-table or Sig value (p-value) $\leq 0.05$, then $\mathrm{H}_{0}$ is rejected. This means that the flexible working arrangement affects the worker's perceived productivity. This study's results are in line with the research results by Staples et al. [2].

The more application of flexible working arrangements during a pandemic outbreak can increase a worker's perceived productivity. This research can contribute as material for consideration in human resource management, where the 
implementation of flexible working arrangements can still be carried out by both government offices and private organisations, even though the pandemic has ended.

\section{CONCLUSION}

Flexible working arrangements have become widely recognized in Indonesia since the existence of government regulation as of March 2020, which regulates the implementation of a work-from-home system that emerged due to overcoming and preventing the spread of Covid 19 in Indonesia. The work system applied to workers is the WFH work system and the picket work system (alternating WFH and WFO). Based on the research results, the average total score for the variable flexible working arrangement, and perceived productivity is in the high category. It means, first, the attitude of workers towards flexible work is high. This happens because workers feel that flexible work arrangements can balance home and work life and workers who can determine the time for work and personal affairs. Second, the perceived value of productivity in the high category indicates that individual perceptions of work results are following predetermined targets.

The simple regression test results to test whether there is an effect of the application of a flexible work system on perceived productivity indicate that the application of a flexible work system can affect perceived productivity. This is because the implementation of flexible work arrangements can positively impact increasing work productivity, both in terms of the organization and the employees concerned. Not only productivity, worker satisfaction and morale can also increase with the application of this flexible working arrangements.

\section{REFERENCES}

[1] P. Costello, Budget paper No 5: Intergenerational Support [Online]. Retrieved from: Http://Www.Budget.Gov.Au/2002-3/Bp5/Html/, 2002.

[2] D.S. Staples, J.S. Hulland and C.A. Higgins, “A Self $\neg$ Efficacy Theory Explanation for the Management of Remote Workers in Virtual Organisations," Organization Science, vol. 10, no. 6, pp. 758-776, 1999.

[3] M. Gamal Aboelmaged and S. Mohamed el Subbaugh, "Factors Influencing Perceived Productivity of Egyptian Teleworkers: an Empirical Study," Measuring Business Excellence, vol. 16, no. 2, pp. 3$22,2012$.
[4] Y. Baruch, "The autistic society,"Information \& Management, vol. 38 no. 3, pp. 129-136, 2001.

[5] T.A. Scandura and M.J. Lankau, "Relationships of gender, family responsibility and flexible work hours to organizational commitment and job satisfaction," Journal of Organizational Behavior: The International Journal of Industrial, Occupational and Organizational Psychology and Behavior, vol. 18, no. 4, pp. 377-391, 1997.

[6] S. Montreuil and K. Lippel, "Telework and occupational health: a Quebec empirical study and regulatory implications," Safety Science, vol. 41, no. 4, pp. 339-358, 2003.

[7] L.T. Thomas and D.C. Ganster, "Impact of family-supportive work variables on work-family conflict and strain: A control perspective," Journal of applied psychology, vol. 80, no. 1, pp. 6, 1995.

[8] E. Galinsky and P.J. Stein, "The impact of human resource policies on employees: Balancing work/family life," Journal of Family Issues, vol. 11, no. 4, pp. 368-383, 1990

[9] O. Mungkasa, "Bekerja dari Rumah (Working From Home/WFH) Menuju Tatanan Baru Era Pandemi COVID 19," Jurnal Perencanaan Pembangunan: The Indonesian Journal of Development Planning, vol. 4 , no. 2, pp. 126-150, 2020.

[10] L. Gren, "The links between agile practices, interpersonal conflict, and perceived productivity," In Proceedings of the 21st international conference on evaluation and assessment in software engineering, pp. 292-297, 2017.

[11] D.S. Sink and G.L. Smith Jr, "The influence of organizational linkages and measurement practices on productivity and management," Organizational linkages: Understanding the productivity paradox, pp. 131-160, 1994.

[12] D. Beaton, C. Bombardier, R. Escorpizo, W. Zhang, D. Lacaille, A. Boonen and P.S. Tugwell, "Measuring worker productivity: frameworks and measures," The Journal of rheumatology, vol. 36, no. 9, pp. 21002109, 2009

[13] D.J. Neufeld and Y. Fang, "Individual, social and situational determinants of telecommuter productivity," Information \& Management, vol. 42, no. 7, pp. 1037-1049, 2005.

[14] E.J. Hill, A.J. Hawkins and B.C. Miller, "Work and family in the virtual office: Perceived influences of mobile telework," Family relations, pp. 293-301, 1996.

[15] P.L. Mokhtarian and I. Salomon, "Modeling the desire to telecommute: The importance of attitudinal factors in behavioral models," Transportation Research Part A: Policy and Practice, vol. 31, no. 1, pp. 35-50, 1997.

[16] L.E. Duxbury, C.A. Higgins and S. Mills, "After-hours telecommuting and work-family conflict: A comparative analysis," Information Systems Research, vol. 3, no. 2, pp. 173-190, 1992.

[17] M.J. Albion, "A Measure of Attitudes Towards Flexible Work Options," Australian Journal of Management, vol. 29, no. 2, pp. 275-294, 2004 